\title{
Development of a Multiplex RT-PCR for the Simultaneous Detection of Three Viruses in Cherry Plants
}

*Corresponding author

Tel: +82-54-912-0241

Fax: +82-54-912-0277

E-mail: hskim98@korea.kr

\author{
Chung Youl Park', Jeongran Park', Geunsik Lee ${ }^{1}$, Seung-In Yi ${ }^{1}$, Byeong Hoon Kim², \\ Jung Sik Eom², Som Gyeol Lee ${ }^{2}$, and Hongsup Kim ${ }^{1}$ * \\ ${ }^{1}$ Seed Testing \& Research Center, Korea Seed \& Variety Service, Gimcheon 39660, Korea \\ ${ }^{2}$ Daegu Agricultural Technology Center, Daegu 41159, Korea
}

Received June 28, 2018 Revised July 18, 2018 Accepted July 18, 2018

\begin{abstract}
A multiplex RT-PCR (mRT-PCR) assay was developed for the detection of the recently reported viruses, Cherry virus $A(C V A)$, Little cherry virus 1 (LChV-1), and Little cherry virus 2 (LChV-2), in cherry plants in Korea. Eight sets of primers were designed for each virus and their specificity was tested by using various combinations of mixed primer sets. From the designed primer sets, one combination was selected and further evaluated to estimate the optimum temperature and detection limits of the mRT-PCR. A newly developed mRT-PCR assay was also tested using 20 cherry samples collected in the field. This MRT-PCR assay may be a useful tool for field surveys of diseases and the rapid detection of these three viruses in cherry plants.
\end{abstract}

Keywords: Cherry virus A, Little cherry virus 1, Little cherry virus 2, Multiplex RT-PCR
As climate change and free trade agreements increase, the domestic introduction of various tropical plants into Korea is increasing. The introduction of new plants increases the potential for novel and unreported pathogens, and could have effects on the domestic ecosystem (Lee et al., 2011).

With the rising demand of cherry, one of the various subtropical crops that is considered a minor fruit crop in Korea, its cultivation area continues to increase through regional specialization (Cho et al., 2018; Kang et al., 2007). Cherry plants are categorized into two species: sweet cherry (Prunus avium L.) and sour cherry (Prunus cerasus L.); sweet cherry is more widely cultivated than sour cherry (Prunus cerasus L.) in Korea. Until now, seven viruses [Apple chlorotic leaf spot virus (ACLSV), Apple mosaic virus (ApMV), Cherry necrotic rusty mottle virus (CNRMV), Cherry virus A (CVA), Cherry green ring mottle virus (CGRMV), Little cherry virus 1 (LChV-1), and Little cherry

Research in Plant Disease

pISSN 1598-2262, elSSN 2233-9191

www.online-rpd.org virus 2 (LChV-2)] from sweet cherry have been reported in Korea (Cho et al., 2013, 2014, 2018; Lee et al., 2014a). Of these, three viruses (CNRMV, LChV-1, and LChV-2) were designated as quarantine viruses by the Animal and Plant Quarantine Agency (QIA). A duplex-PCR assay has been previously developed for the detection of CGRMV and CNRMV (Lee et al., 2014b). However, simultaneous diagnostic methods, which include LChV-1 and LChV-2, have not been developed in Korea. In recent years, CVA and LChV-1 have been reported in Prunus species such as peach tree (Prunus persica) and Japanese apricot (Prunus mume) (Jo et al., 2017; Lim et al., 2015; Lim et al., 2017, Koinuma et al., 2016). Moreover, LChV2 is known to be transmitted by the apple mealybug (Phenacoccus aceris) (Signoret) and grape mealybug (Pseudococcus maritimus) (Ehrhorn) (Mekuria et al., 2013; Raine et al., 1986). To minimize the damage caused by these viruses, a rapid and accurate diagnostic system is vital. mRT-PCR has the benefit of being able to detect multiple target pathogens in a single reaction, reducing the time and cost of diagnosing these samples individually (Asano et al., 2015; Yao et al., 
2014). This study was, therefore, undertaken to develop an mRT-PCR assay for the simultaneous detection of CVA, LChV1 , and LChV-2 in cherry plants.

Plant materials. Two cherry leaf samples were put together and then grind the samples in liquid nitrogen for a positive control. One sample was infected with CVA and LChV-2, and the other sample was infected with CVA and LChV-1. These samples were registered in NCBI GenBank with accession no. MF083705 (LChV-1) and MF083705 (LChV-2) (Cho et al., 2018).

Total RNA extraction and cDNA synthesis. Total RNA was extracted from the samples using the Nuclisens EasyMag bio-robot (Biomérieux, Marcy l'Etoile, France) and eluted in a volume of $50 \mu \mathrm{l}$. The concentration and purity of the extracted total RNA was measured using Tecan Infinite M200 Pro (Tecan Group Ltd., Männedorf, Switzerland) and was estimated to be $88.32 \mathrm{ng} / \mu \mathrm{l}$. First-strand cDNA was synthesized using M-MLV (Invitrogen, Life Technologies, Carlsbad, CA) with random N25 primers, according to the manufacturer's instructions.

Virus-specific primer design. To design each virusspecific primer pair, the complete nucleotide sequence of each virus was downloaded from the NCBI GenBank database. Six types of CVA isolates and one other member of the Capillovirus genus were used for CVA-specific primer design. The LChV-1 and LChV-2-specific primer pairs were designed similarly to the CVA primer. All downloaded sequences were aligned using DNAMAN software ver. 7.0 (Lynnon BioSoft, Quebec, Canada). Specific primer pairs were designed based on highly conserved regions of their target viruses, with a total of eight primer pairs de- signed for each virus.

PCR amplification and primer selection. The specificities of the designed primers were tested by monoplex RT-PCR with $2 X$ TOPsimple DyeMix (aliquot)-HOT premix (Enzynomics, Daejeon, Korea). For PCR amplification, $3 \mu \mathrm{l}$ of the cDNA template was used in a $20 \mu \mathrm{l}$ reaction volume. PCR conditions were as follows: initial denaturation at $95^{\circ} \mathrm{C}$ for $10 \mathrm{~min} ; 35 \mathrm{cycles}$ at $95^{\circ} \mathrm{C}$ for $30 \mathrm{~s}, 55^{\circ} \mathrm{C}$ for $30 \mathrm{~s}$ and $72^{\circ} \mathrm{C}$ for $1 \mathrm{~min}$; and a final extension at $72^{\circ} \mathrm{C}$ for $5 \mathrm{~min}$. The sizes of the PCR products were confirmed on a $1 \%$ agarose gel stained with EcoDye DNA Stain (SolGent Co., Daejeon, Korea). Amplicons were purified using the Expin PCR SV kit (GeneAll, Seoul, Korea) and sequenced directly using each primer. All species-specific primers designed for the three viruses were successfully amplified by the monoplex RT-PCR reaction and direct sequencing results confirmed the target viral sequences. Of three target viruses, four CVA primer pairs were selected, based on band intensity, and then combined with LChV-2 primer pairs for duplex RT-PCR. Among the 22 duplex RT-PCR (CVA+LChV-2) combinations, seven were selected, and then 28 primer pairs were combined with LChV1 for $\mathrm{mRT}$-PCR. Ten primer combinations were found to be effective in mRT-PCR, and finally one combination [CVA (270 bp)+LChV-2 (570 bp)+LChV-1 (427 bp)] was selected based on band intensity, sharpness, and target sizes (Table 1, Fig. 1A).

Optimization and sensitivity of multiplex-PCR. Different concentrations of primer pairs and annealing temperatures were tested to optimize the simultaneous detection of the three viruses. A range of annealing temperatures were compared, from 55 to $60^{\circ} \mathrm{C}$, using PCR gradient analysis.

When $\mathrm{mRT}$-PCR was performed using the same primer

Table 1. Oligonucleotide sequences of a multiplex-PCR for the detection of the three viruses

\begin{tabular}{cllcc}
\hline Virus name & Primer name & \multicolumn{1}{c}{ Sequences $\left(\mathbf{5}^{\prime}\right.$ to $\left.\mathbf{3}^{\prime}\right)$} & Target* & Amplicon size \\
\hline CVA & CVA-D-F2 & AGTGCTCACAGCTGTAAAAG & MP & $270 \mathrm{bp}$ \\
& CVA-D-R3 & CTAAAACCTGCTTGGCATGC & & p53 \\
LChV-2 & LCh2-D-F1 & TCGTGTATAGACCTTGTATGA & $\mathrm{bp}$ \\
& LCh2-D-R1 & AAACTTCGAGAACCGGACTC & CP & $427 \mathrm{bp}$ \\
LChV-1 & LCh1-D-F2 & GAAGCCTTGAAACTTCTGACA & & \\
& LCh1-D-R3 & CTAATTAGTGTAGTCGATGT & & \\
\hline
\end{tabular}

${ }^{*}$ All primers for each virus were designed within the conserved regions: CP (coat protein), MP (movement protein), p53 (protein 53 ). 


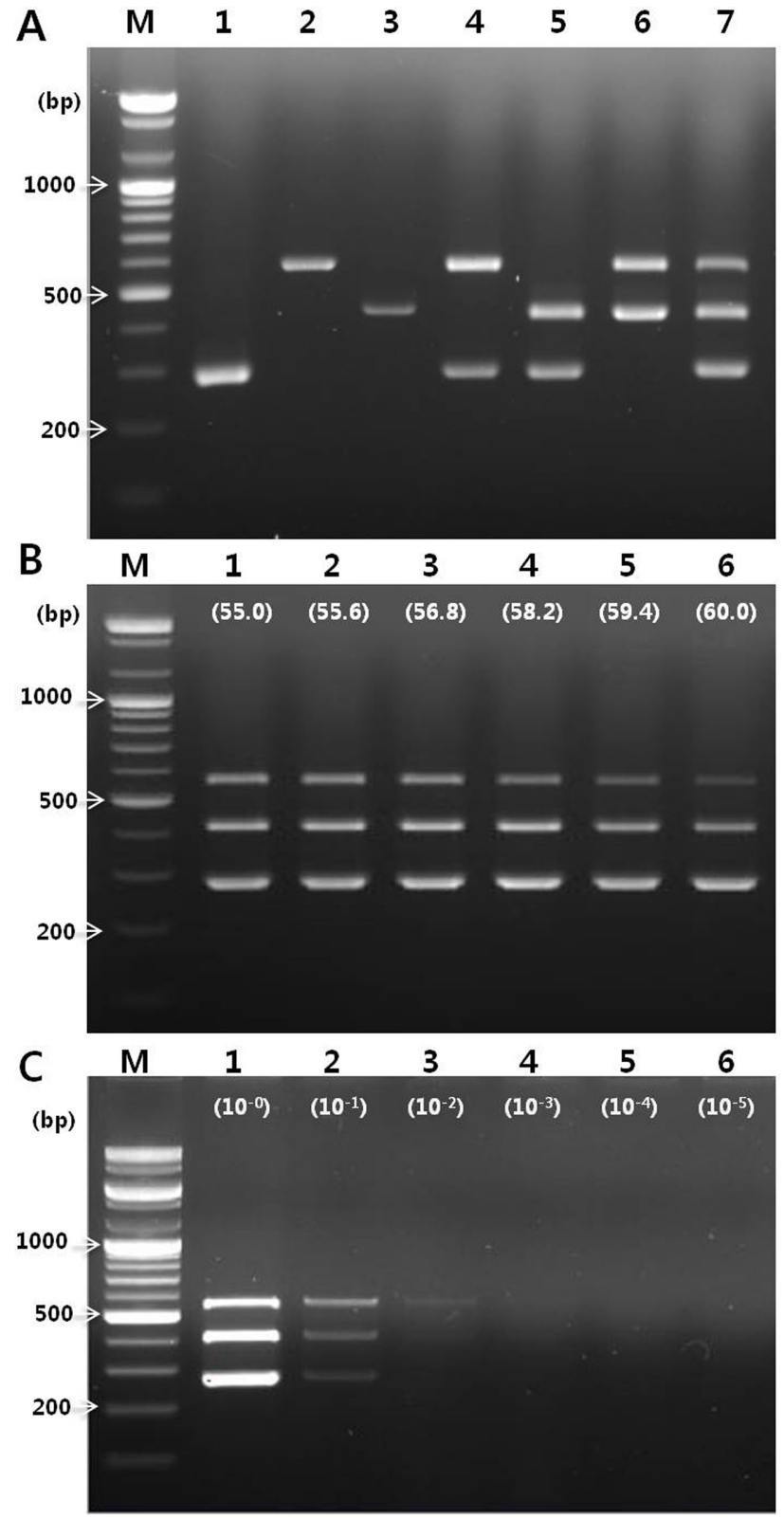

Fig. 1. (A) Simultaneous detection using the selected primer sets for the three viruses (Cherry virus A, CVA; Little cherry virus 1, LChV-1; and Little cherry virus 2, LChV-2) by multiplex PCR. Lane M: $1 \mathrm{~kb}$ DNA ladder (Bioneer, Daejeon, Korea), Lane 1: Cherry virus A (CVA), Lane 2: Little cherry virus 2 (LChV-2), Lane 3: Little cherry virus 1 (LChV-1), Lane 4: CVA + LChV-2, Lane 5: CVA + LChV-1, Lane 6: LChV-2 + LChV1, Lane 7: CVA+LChV-2+LChV-1, (B) Optimization temperature test, (C) Sensitivity test.

concentrations, the resulting CVA positive band intensity was strong, while LChV-1 and LChV-2 were weak. Therefore, mRT-PCR was performed by adjusting the primer concentration to 5,10 , and 20 pmole. As a result, the positive band intensity of the three viruses was equaled. Among the five different annealing temperature conditions, the optimal annealing temperature was confirmed as $56.8^{\circ} \mathrm{C}$ (Fig. 1B).

To confirm the sensitivity of the PCR detection assay, a 10fold serial dilution was conducted up to $10^{-5}$ by monoplex RT- and multiplex RT-PCR, using CDNA templates. In the monoplex RT-PCR, the detection limit was $10^{-2}$ for CVA and $10^{-1}$ for both LChV-1 and LChV-2. Using mRT-PCR, amplification products were observed up to $10^{-1}$, whereas only CVA was detected up to $10^{-2}$ (Fig. 1C). The annealing temperature and individual primer concentrations are suitable for detecting all three viruses. These results show that the detection limit is lower than the total amount of RNA which was extracted from other crops and/or plants (Lee et al., 2017; Nam et al., 2015; Yu et al., 2013). In our study, we believe the low detection limit was due to the low concentration of the first extracted total RNA and that the detection limit range could be increased if higher concentration of total RNA was extracted.

Application for cherry plants infected in field. In May 2018, a total twenty cherry leaf samples were collected from Gyeongju ( $n: 12)$ and Daegu city ( $n: 8)$ for virus testing. The collected samples showed typical virus-like symptoms, including mosaic, malformation, and red ring spots on the leaves (Fig. 2). All samples were tested using the developed monoplex RT- and mRT-PCR. The test results showed that all twenty samples were positive for CVA, four were coinfected with CVA+LChV-1, and six were coinfected with CVA+LChV2. Monoplex RT-PCR results were consistent with the mRTPCR assay (Data not shown). The monoplex RT- and mRT$P C R$ results did not show any non-target bands or PCR dimers. These results imply that the newly developed $\mathrm{mRT}$ PCR assay for the three viruses (CVA, LChV-1, and LChV-2) enable their simultaneous detection in infected cherry plants.

As previously reported by Cho et al. (2014), the CVA and CNRMV co-infection rate was very low $(0.6 \%)$ in sweet cherry samples. To confirm this in our samples, an additional PCR was carried out to detect CNRMV using same primer pairs. However, our survey results confirmed that the CVA and CNRMV infection rate (50\%) was higher than the above results. Cherry virus surveys have only been performed in certain areas, and a nationwide survey will therefore be needed to assess the prevalence of cherry virus diseases in Korea. The $m R T-P C R$ we have developed and the overall findings of this study could contribute to the development of new methods 


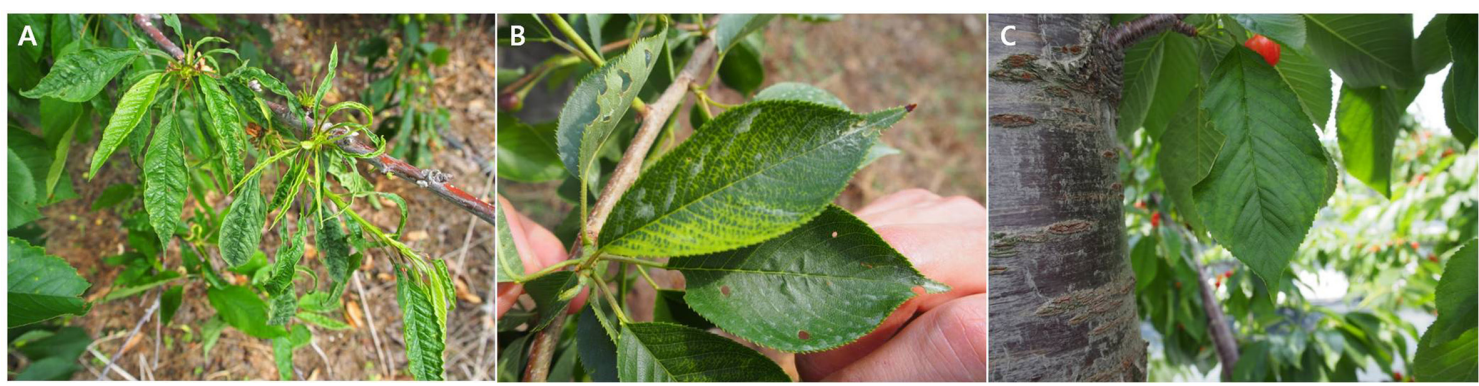

Fig. 2. Virus symptoms observed on the leaves of cherry plants. (A) Malformation symptoms and coinfection with CVA and LChV-2, (B) Vein clearing and coinfection with CVA and LChV-1, (C) Mosaic and infection with CVA.

for the rapid detection of plant viruses and field surveys.

\section{Conflicts of Interest}

No potential conflict of interest relevant to this article was reported.

\section{Acknowledgments}

The first author would like to thank Miss Hyein Kim (Korea seed \& variety service, Seed testing \& research center) for administrative support.

\section{References}

Asano, S., Matsushita, Y., Hirayama, Y. and Naka, T. 2015. Simultaneous detection of Tomato spotted wilt virus, Dahlia mosaic virus and Chrysanthemum stunt viroid by multiplex RT-PCR in dahlias and their distribution in Japanese dahlias. Lett. Appl. Microbiol. 61: 113-120.

Cho, I. S., Choi, G. S. and Choi, S. K. 2013. Identification of Cherry green ring mottle virus on sweet cherry trees in Korea. Res. Plant Dis. 19: 326-330. (In Korean)

Cho, I. S., Choi, G. S., Choi, S. K., Seo, E. Y. and Lim, H. S. 2014. First report of Cherry necrotic rusty mottle virus infecting sweet cherry trees in Korea. Plant Dis. 98: 164.

Cho, S.-Y., Kim, H. and Yi, S.-I. 2018. First report of Little cherry virus 1 and 2 in sweet cherry in Korea. Plant Dis. 102: 1045.

Jo, Y., Lian, S., Cho, J. K., Chu, H., Choi, H. and Cho, W. K. 2017. First Report of Asian prunus virus 2 and Cherry virus A Infecting Japanese Apricot (Prunus mume) in Korea. Plant Dis. 101: 1683.

Kang, J. K. and Cho, G. R. 2007. Production situation and demand estimates of cherry (Prunus avium L.) in Korea. J. Korean Soc. Int. Agric. 19: 214-223. (In Korean)

Koinuma, H., Nijo, T., Iwabuchi, N., Yoshida, T., Keima, T., Okano, Y. et al. 2016. First complete genome sequence of Cherry virus $A$. Genome Announc. 4: e00498-16.
Lee, B.-C., Bae, J.-Y., Kim, S.-M., Ra, J.-E., Choi, N. J., Choi, M. Y. et al. 2017. Simultaneous detection of barley virus diseases in Korea. Res. Plant Dis. 23: 363-366. (In Korean)

Lee, J. S., Cho, W. K., Choi, H. S. and Kim, K. H. 2011. RT-PCR detection of five quarantine plant RNA viruses belonging to Poty and Tospoviruses. Plant Pathol. J. 27: 291-296.

Lee, S. Y., Yea, M. C., Back, C.G., Kang, I. K., Choi, C., Lee, S. H., et al. 2014a. Occurrence of cherry necrotic rusty mottle virus (CNRMV) and cherry green ring mottle virus (CGRMV) on sweet cherry. J. Fac. Agr. Kyushu U. 59: 1-4.

Lee, S. Y., Yea, M. C., Back, C. G., Choi, K. S., Kang, I. K., Lee, S. H. et al. 2014b. Survey of Cherry necrotic rusty mottle virus and Cherry green ring mottle virus incidence in Korea by Duplex RT-PCR. Plant Pathol. J. 30: 445-449.

Lim, S., Igori, D., Yoo, R. H., Zhao, F., Cho, I. S., Choi, G. S. et al. 2015. Genomic detection and characterization of a Korean isolate of Little cherry virus 1 sampled from a peach tree. Virus genes. 51: 260-266.

Lim, S., Igori, D., Baek, D., Cho, I. S., Choi, G. S. and Moon, J. S. 2017. First report of cherry virus $A$ infecting Prunus mume in South Korea. Virusdisease 28: 220-221.

Mekuria, T. A., Smith, T. J., Beers, E., Watson, G. W. and Eastwell, K. C. 2013. Little cherry virus 2 is transmitted to sweet cherry by Pseudococcus maritimus (Ehrhorn), a new vector of this virus. Plant Dis. 97: 851.

Nam, M., Lee, Y. H., Park, C. Y., Lee, M. A., Bae, Y. S., Lim, S. et al. 2015. Development of multiplex RT-PCR for simultaneous detection of garlic viruses and the incidence of garlic viral disease in garlic genetic resources. Plant Pathol. J. 31: 90-96.

Raine, J., McMullen, R. D. and Forbes, A. R. 1986. Transmission of the agent causing little cherry disease by the apple mealybug Phenacoccus aceris and the dodder Cuscuta lupuliformis. Can. J. Plant Pathol. 8: 6-11.

Yao, B., Wang, G., Ma, X., Liu, W., Tang, H., Zhu, H. et al. 2014. Simultaneous detection and differentiation of three viruses in pear plants by a multiplex RT-PCR. J. Virol. Methods. 196: 113-119.

Yu, Y., Zhao, Z., Jiang, D., Wu, Z. and Li, S. 2013. A one-step multiplex RT-PCR assay for simultaneous detection of four viruses that infect peach. Lett. Appl. Microbiol. 57: 350-355. 